\title{
Функции и полномочия Суда ЕС, \\ его роль в институциональной структуре Европейских Сообществ
}

Тихоновечкий Д.С.*

Как известно, положение Суда ЕС в институциональной структуре Европейского Сообщества, юрисдикиионные полномочия и порядок формирования перечислены в ряде статей Договора об учреждении Европейского Сообщества (далее - Договор о ЕС) со всеми последуюшими изменениями. Этому, в частности, посвящен подраздел 4 Договора.

Основная особенность функционирования Суда ЕС как одного из пяти институтов ЕС заключается в том, что в рамках одного института функционируют два органа: непосредственно Суд ЕС и Суд первой инстанции, который появился в 1988 году благодаря поправкам в учредительном договоре, внесенным Единым Европейским Актом. Суд первой инстанции действует «при Суде $\mathrm{EC}{ }^{1}$. Суд $\mathrm{EC} \mathrm{в} \mathrm{отношении}$ решений, принимаемых Судом первой инстанции, выступает в роли апелляционной инстанции, призванной пересматривать вопросы применения права. Помимо этого, стоит отметить, что Суд первой инстанции имеет ограниченную юрисдикцию; ему подсудны лишь рассмотрение трудовых споров в рамках ст. $236^{2}$, дела, связанные с оспариванием решений Совета в рамках статей 33 и 35 Договора об учреждении ЕОУС, споры, истцами по которым выступают частные лица, а также некоторые другие виды споров. Постепенно происходит расширение юрисдикции Суда первой инстанции ${ }^{3}$, однако существует исключительная юрисдикция Суда ЕС. В данном случае уместно вспомнить о существующей в доктрине концепции разделения полномочий Суда ЕС и Суда первой инстанции, которую называют «теорией привилеги-

\footnotetext{
- Тихоновецкий Дмитрий Сергеевич - аспирант кафедры европейского права МГИМО (У) МИД РФ.

'Консолидированный текст Договора о Европейском Союзе и Договора об уиреждснии Европейского Сообщества Ст. 225. // Европейское Право / Под ред. Л.М. Энтина. M., 2000. C. 660 .

'Ibidem. C. 665.

${ }^{3}$ Так, с 1993 года Суд первой инстанции имеет право рассматривать, в частности, иски об аннулировании, связанные с договорной и внедоговорной ответственностью, иски связанные с антидемпинговыми мерами, и т.п.
} 
рованных истцов». Согласно данной теории, разделение полномочий между двумя органами происходит следующим образом: Суд первой инстанции призван рассматривать иски, вчиняемые физическими и юридическими лицами, государствами, не являющимися членами ЕС (т.н. «непривилегированными истцами»). Соответственно, «привилегированные истцы» (т.е. институты, государства - члены ЕС) пользуются правом обрашаться непосредственно в Суд ЕС. Более того, на «привилегированных истцов» не распространяются существенные требования, соответствие которым необходимо для возникновения права для подачи иска в Суд ЕС для «непривилегированных истцов»: требования относительно «прямой и непосредственной заинтересованности». Следует также вспомнить положения ст. 225 Договора о ЕС, которые прямо указывают, что Суд первой инстанции не имеет полномочий выносить решения в преюдициальном порядке. Об этом, в частности, писали профессор Дж. Вайлер в книге, посвяценной деятельности Суда $\mathrm{EC}^{4}$, а также Пол Крейг и Грэнн де Бурка ${ }^{5}$. Договор, подписанный в Ницце, тем не менее, содержит ряд положений, согласно которым Суд первой инстанции получит полномочия, выходящие за рамки доктрины «привилегированных истцов».

Основные вопросы процедуры принятия решений перечислены в статьях 221, 222 и в Регламентах Суда ЕС и Суда первой инстанции.

Вопросы процедуры сыграли определенную роль в превращении Суда ЕС в своеобразный «мотор гармонизации» права в ЕС. Об этом, в частности, пишет Родригес Иглесиас в своем докладе в качестве Председателя Суда $\mathrm{EC}^{6}$. Дело заключается в том, чго Суд ЕС, орган независимый, выносит свои решения от имени всего Суда в соответствии с принципом тайны судебного совещания. То, что Суд не связан своими предыдущими решениями, придает его деятельности и решениям огромный авторитет ${ }^{7}$.

Обращаясь к центральному вопросу настоящей статьи, к вопросу о юрисдикции Суда ЕС и об основных формах реализации этой юрис-

${ }^{4}$ Constitutional or International? The Foundation of the Community Legal Order / Slaughter, Sweet, Weiler ed ads. The European court of Justice and National Courts - Doctrine and Jurisprudence: Legal change in its sucial context. - London, 1998. P. 352.

${ }^{5}$ Paul Craig, Grainne de Burca. EC Law. - Oxford, 1997. P. 457-458.

'Gil Carlos Rodriguez Iglesias. Le pouvoir judiciaire de la Communauté européenne au stade actuel de l'évolution de l'Union. Conférence Winston Churchill. 7me session de l'academie du droit europeen, Institut Universitaire europeen, Florence, ler juillet 1996. S. 6.

'Ibidem, P. 6-7. 
дикции, необходимо обратить внимание на ряд статей Договора об учреждении Европейского Сообщества. Прежде всего следует обратиться к ст. 220 (бывшая ст. 164), которая гласит: «Суд ЕС обеспечивает применение права Сообщества посредством единообразного толкования и применения настояшего Договора ${ }^{8}$. Как отмечают многочисленные комментаторы, данная статья является центральной для толкования объема юрисдикции Суда ЕС. Так, например, Ханс Крюк в своем комментарии к Договору о ЕС пишет, что именно данная статья дает расширительное толкование полномочий Суда ЕС, что, по сути, позволяет самому Суду определять рамки своей компетенцин 9 .

Чрезвычайно важную роль в формировании юрисдикционного поля Суда ЕС играют также статьи 226, 227, 228, 230, 231, 232, 234, 237. Именно эти статьи и являются источником прямых и подразумеваемых полномочий Суда ЕС. Как уже отмечалось выше, именно на основании данных положений Договора Суд ЕС выводит концепцию «подразумеваемых» полномочий, хотя это и противоречит положениям ст. 7 Договора о ЕС и ст. 3 Евратома, согласно которым Суд ЕС, являясь институтом Сообщества, должен действовать «в рамках полномочий, предоставленных ему этим Договором» ${ }^{10}$.

Юрисдикция Суда ЕС, направленная на выполнение его основной задачи как Института Сообщества ст. 220 Договора о ЕС, заключается в следующем. Во-первых, Суд обладает полномочнями выносить решения относительно сушествования факта нарушения одним из государств-членов обязательств, перечисленных в Договоре об учреждении ЕС". Во-вторых, Суд ЕС наделяется «неограниченной юрисдикцией» в отношении санкций, предусмотренных в Регламентах ${ }^{12}$. В-третьих, Суд обладает необходимыми полномочиями «контролиро-

\footnotetext{
${ }^{8}$ Консолидированный текст Договора о Европейском Союзе и Договора об учреждении Европейского Сообщества // Европейское Право/ Под ред. Л.М. Энтина. М., 2000. C. 659 .

${ }^{9}$ Kommentar zum EU- /EG -Vertrag. Band 4 / Baden-Baden, 1997 - Artikel 164, P. 373; cM. также paбory L. Neville Brown and Tom Kennedy. The Court of Justice of the European Community. - London, 1995. P. 345 - 347.

${ }^{10}$ Консолидированный текст Договора о Европейском Союзе и Договора об учреждении Европейского Сообщества // Европейское Право / Под ред. Л.М. Энтина. М., 2000. С. 558; а таюже Договор об учреждении Евратома / Договоры, учреждающие Европейские Сообщества/ Под ред. Ю.А. Борко, М.В. Каргалова, Ю.М. Юмашева. М., 1994. C. 296.

${ }^{11} \mathrm{CT} .228$ Доповора о ЕC.

${ }^{12}$ Ст. 229 Договора о ЕС.
} 
вать законность» актов Сообщества, порождающих правовые последствия для третьих лиц ${ }^{13}$. В-четвертых, Суд имеет право выносить решения в преюдициальном порядке в рамках ст. 234 Договора о ЕС. Решения, выносимые в преюдициальном порядке, представляют собой один из наиболее эффективных инструментов взаимодействия Суда ЕС и национальных судов в государствах-членах. Посредством данного инструмента Суд ЕС имеет возможность добиваться единообразного толкования и применения норм Сообщества (в том числе и сформулированных и им самим) в государствах-членах. Важно отметить, что именно в решениях, выносимых в преюдициальном порядке, Суд ЕС реализует свои нормотворческие полномочия. Данный институт деятельности Суда ЕС необходимо рассматривать отдельно, поскольку ст. 234 , как впрочем, и, ст. 220 , представляет собой важнейший инструмент, благодаря которому практика Суда становится источником права ЕС. В-пятых, Суд ЕС имеет полномочия рассматривать споры и присуждать возмещение ушерба, причиненного актами или действиями институтов или их служащими ${ }^{14}$. В-шестых, Суд ЕС имеет полномочия принимать решения о неприменении регламента в споре, затрагивающем вопрос о действительности данного регламента ${ }^{15}$. В-седьмых, выносить решения в рамках процедуры апелляции на решение Суда первой инстанции ${ }^{16}$. Среди других полномочий можно назвать: полномочия Суда разрешать споры между служашими Сообщества и Сообществом; разрешать споры согласно арбитражной оговорке ${ }^{17}$ или переданные на рассмотрение Суда в силу специального соглашения сторон $^{18}$; разрешать споры в силу ст. 237, возникающие из обязательств согласно Уставу Европейского инвестиционного банка или Уставу Европейского центрального банка (ЕЦБ).

Данные полномочия Суда ЕС вытекают из Договора об учреждении Европейского Сообшества. Однако сушествует еше ряд полномочий Суда ЕС, предусмотренных Маастрихтским и Амстердамским договорами. Так, например, Амстердамский договор распространил полномочия Суда ЕС на так называемую третью опору Европейского Союза, охватывающую сотрудничество полиций и судов в утоловно-правовой

\footnotetext{
${ }^{13}$ Ст. 230 и 232 Договора о ЕС.

${ }^{14} \mathrm{Cr} .235,258$ Договора о ЕС.

${ }^{15} \mathrm{CT} .241$ Договора о ЕC.

${ }^{16} \mathrm{Cr} .225$ Договора о ЕC.

${ }^{17}$ Ст. 238 Договора о ЕС. Речь идет о контрактах, заключенных от имени Сообшеств.

${ }^{18} \mathrm{C}$. 240 Договора о ЕС.
} 
сфере, а также предусмотрел полномочия выносить решение в преюдициальном порядке по вопросам визовой политики, предоставления убежища и иммиграции. Суд ЕС имеет право также толковать и выносить решения в преюдициальном порядке по ряду международных конвенций, заключенных государствами- членами: Брюссельская конвенция о подсудности и исполнении решений по гражданским и торговым делам, а также соглашения о Европейской ассоциации свободной торговли ${ }^{19}$.

Как представляется, необходимо обратить внимание также на формальную сторону вопроса об осуществлении Судом ЕС своих полномочий. Поэтому ниже будет сделана попытка рассмотреть те виды исков, в решении по которым Суд $\mathrm{EC}$ и формулирует, и интерпретирует большинство норм права. Ведь формально Суд ЕС не дает официального толкования права ЕC, а все принципиальные вопросы, связанные с толкованием, разрешаются лишь применительно к конкретному делу.

Можно выделить три основные группы исков, которые Суд ЕС полномочен рассматривать (перечень исков, представленный в Договоре об учреждении ЕС, является закрытым). Первая группа исков - это иски из неисполнения обязательств. Вторая - иски о судебном контроле за законностью. И последняя группа - это иски о возмещении вреда из неисполнения договорных обязательств, а таюже связанные с внедоговорной ответственностью Сообщества. По всем трем группам исков, выносимых в рамках прямой юрисдикции Суда, Суд ЕС имеет полномочие выносить решение по существу дела; автор не рассматривает в данной статье иски, передаваемые в преюдициальном порядке, поскольку данный институт носит принципиально иной характер и должен быть рассмотрен отдельно.

Как отмечают специалисты, основное значение имеют иски, основанием для которых служат действия (или бездействие) государствчленов ${ }^{20}$.

Итак, рассмотрим погномочия Суда ЕС принимать решения в спорах из неисполнения обязательств. Как уже упоминалось, иски из неисполнения обязательств подаются на основании ст. 227 Договора об учреждении Европейского Сообщества. Предметом нарушения являются обязательства государств-членов из учредительных договоров, однако Суд ЕС пошел дальше и распространил ответственность

${ }^{19}$ C. 293 Договора о EC; [1972] OJ L299/32, [1983] OJ C97/23.

${ }^{20}$ Европейское право / Под ред. Л.М. Энтина. М., 2000. С. 165. 
государств-членов таюже и на случаи нарушения норм вторичного права EC, которые порождают юридические последствия для сторон. В качестве примера можно привести судебное дело Commission v. Italy ${ }^{21}$, а также ряд аналогичных дел (Commission v. France ${ }^{22}$ и т.д.). Таким образом, Суд расширил понимание объема ответственности государств-членов. Другим важным вопросом в этой связи является стремление Суда ЕС объединить ответственность государств-членов за нарушения обязательств, вытекающих из права Сообществ, и ответственность на основании ст. 288 Договора о Европейском Сообществе $^{23}$. В качестве показательного примера данного подхода в практике Суда, существенным образом дополняющей полномочия Суда $\mathrm{EC}$, можно назвать ряд дел: Brasserie du Pécheur \& Factortame III ${ }^{24}, \mathrm{R}$ v. HM Treasury, ex parte British Communications ${ }^{25}$. Все эти судебные решения появились как продолжение развития судебной практики Суда ЕС, относящей к своим полномочиям рассмотрение споров об ответственности государств-членов, впервые затронув серьезным образом этот вопрос в Деле Frankovich" ${ }^{26}$.

В вышеуказанном Деле Frankovich Суд впервые обратился к вопросу об ответственности государств-членов за нарушение норм права Сообществ. Один из основных выводов, сделанных Судом по этому делу, заключается в том, что Суд вывел существование особого принципа права Сообщества, значение которого вытекает из общего смысла и целей Договора о Европейском Сообществе. Согласно выведенной Судом ЕС норме права, у частных лиц появляется право требования возмещения убытков в случае, если нарушение государствомчленом права Сообщества отвечает трем основным требованиям. Во-первых, должна быть причинно-следственная связь между причинением ущерба и возникшими убытками; во-вторых, нарушение конкретной нормы права Сообществ должно быть связано с нарушением

\footnotetext{
2!Дело C-8/70, Commission v. Italy, [1970] ECR 961.

"2Дело C-11/69, Commission v. France, [1969] ECR 523. European University Institute, Working Paper № 1997. P.15.

24Дело C-46/93 \& C-48/93, [1996] I CMLR 889.

"Дело C-392/93, [1996] 2 CMLR 217.

${ }^{26}$ Дело С-6/90 \& C-9/90, Frankovich \& Others, [1991], ECR 1-5357.
}

${ }^{23}$ Gerrite Betlem. The King Can Do Wrong: State Liability for Breach of European Community Law in the Post-Frankovich era / Web Journal of Current Legal Issues. Blackstone Press Ltd., 1996. P. 2, a такое см. Ari Affilalo. How Far Frankovich? Effective judicial protection and associational standing to Litigate diffuse interests in the European Union / 
прямо предоставленных частным лицам прав; в-третьих, данные права должны быть четко оговорены в том акте Сообества, на нарушение которого принесена жалоба. Дальнейшее развитие этого принципа было предпринято в 1996 году в решениях по делам Factortame и Brasserie, о которых уже упоминалось выше. Суд счел необходимым унифицировать подход к ответственности за нарушение права Сообщества как государствами-членами, так и самим Сообществом. Суд при этом ссылался на существование общего для государств-членов принципа права, согласно которому незаконные действия или бездействия являются основанием для возмешения причиненного ушерба. Таким образом, на основании данного принципа ответственность государства-члена в случае нарушения обязательного для него положения нормы вторичного права Сообществ (и которое при этом создает права для частных лиц, т.е. обладает прямым действием) наступает в случае, если нарушены данные права частных лиц, имеется в наличии серьезное и явное нарушение, прямая причинно-следственная связь между ушербом и нарушением. При этом Суд в последуюшем решении по делу Dillenkofer ${ }^{27}$ указал, что критерий серьезного и явного нарушения является презюмируемым, в отличие от остальных, подлежащих доказыванию. Принцип, разработанный и примененный судом в делах Frankovich, Factortame и Brasserie, был в дальнейшем применен в огромном количестве последовавших дел ${ }^{28}$. Однако вопрос о действительном значении критерия наличия «серьезного и явного нарушения» остается открытым. Суд в ряде своих решений, например в решении по делу Kohle v. Austria ${ }^{29}$, рассматривая различные аспекты нарушения права Сообществ государствами-членами, как правило, вообще избегал ответа на вопрос о серьезности имеющегося нарушения. В ряду подобных дел можно указать дело Rechberger \& Others v. Austria ${ }^{30}$, в котором Суд затронул также и вопрос о критерии причинно-следственной связи между ушербом и нарушением. Суд фактически указал на то, что причинно-следственная связь является основным критерием при определении факта наступления ущерба, а также

\footnotetext{
${ }^{27}$ Дело C-178, 179 \& 188-190/94, Dillenkofer \& Others, [1996] ECR I-4845.

${ }^{28}$ Наиболее интересными представляются следующие судебные дела: C-334/92, Wagner Miret v. Fondo de Garantia Salarial, [1993] ECR 1-6911; C-91/92, Faccini Dori v. Recreb [1994] ECR I-3325; C-5/94, Hedley Lomas [1994] ECR I-2553; C-192/95, Comateb \& others, [1997] ECR I-165.

${ }^{29}$ Дело C-302/97, Kohle v. Austria, [1999], ECR I-3099.

${ }^{30}$ Дело C-140/97, Rechberger \& others v. Austria, [1999] ECR I-3499.
} 
что требование о причинно-следственной связи в том виде, в каком оно изложено в решениях Суда ЕС, представляет собой часть права Сообщества, а потому должно соблюдаться единообразно во всех государствах-членах ${ }^{31}$. Таким образом, Суд ЕС оставляет на свое усмотрение вопрос о наличии причинной связи, что в принципе выходит за рамки его компетенции, указанные в учредительных договорах.

Вторая группа исков, которые Суд ЕС полномочен рассматривать, это иски о судебном контроле за законностью. Один из основных исков данной группы - это иски об аннулировании, подаваемые в рамках ст. 230 Договора о ЕС. Данный иск может подаваться как в Суд первой инстанции, так и в Суд ЕС. Объектом судебного контроля в данном случае выступают акты институтов Сообщества, которые являются ultra vires, т.e. приняты без достаточных полномочий у конкретного института на издание подобного акта. Данный иск представляет собой важную часть полномочий Суда ЕС, поскольку позволяет ему контролировать деятельность других институтов Сообщества, а также следить за «разделением властей» в Сообществе. Все акты, порождающие юридические последствия, подлежат контролю со стороны Суда ЕС. Сюда, помимо регламентов, директив и решений, включают и международные договоры, заключенные Сообществом. Об этом, в частности, говорится в Деле SFPI ${ }^{32}$. Здесь, так же как и в случае с исками первой группы, действует критерий «d'intérêt d'action», т.e. прямой и непосредственной заинтересованности частных лиц, или «создания непосредственных прав и обязанностей для частных лиц» ${ }^{33}$, для решения вопроса о допустимости судебного контроля в отношении конкретного акта институтов Сообщества. Данный критерий, однако, остается довольно расплывчатым, оставляя на усмотрение Суда вопрос о допустимости аннулирования рекомендаций или заключений, а также иных актов Сообщества, носящих необязательный характер. Об этом, в частности, пишет Матяйзен ${ }^{34}$. Так, например, в решении по делу Emerald Meats v. Commission ${ }^{35}$ Суд указал, что «заключение..., в котором речь идет об обеспечении эффективного управления..., а также в котором указывается намерение Комиссии принять некоторые меры», не мо-

${ }^{31}$ Gerrit Betlem. Op. cit. P. 7.

${ }^{32}$ Дело C-39/93/P SFPI [1994] ECR I-2681, par. 27.

${ }^{33}$ Дело С-60/81, IBM v. Commission, [1981] ECR 2639 (2651/9). См. также Дело С-108/ 83, Luxembourg v. Parliament, [1984] ECR 1945.

${ }^{34}$ P.S.R.F. Mathysen. A Guide to EU Law. / London, 1999. P. 132.

${ }^{35}$ Дело C-66/91, R Emerald Meats v. Commission, [1991] ECR I-1 I43. 
жет создавать права для частных лиц. Однако, тем не менее, стоит упомянуть дело France v. Commission ${ }^{36}$, в котором Суд аннулировал рекомендованный «кодекс поведения», а также другое дело France v. Commission ${ }^{37}$, в котором Суд аннулировал некоторые внутренние инструкции Комиссии. В отличие от частных лиц, государства-члены и институты (включая ЕЦБ) не обязательно должны иметь непосредственную заинтересованность в аннулировании акта института Сообщества, что в принципе укладывается в уже рассмотренную нами доктрину «привилегированных истцов».

Среди «оснований для аннулирования» можно назвать следуюшие:

1. Превышение полномочий. Данное основание является основным, и именно поэтому Суд принимает к рассмотрению иски из превышения полномочий даже после истечения соответствующего срока ${ }^{38}$.

2. Нарушение необходимой процедуры. Все акты, принятые с нарушениями предусмотренной процедуры принятия нормативно-правовых актов Сообщества, могут быть аннулированы на этом основании.

3. Нарушение положений Учредительного договора или иных норм права, относящихся к порядку его применения. Как уже было сказано выше, Суд ЕС не делает различий между нарушением положений Договора и нарушением иных актов Сообщества, порождающих юридические последствия. Что же касается «норм права, относящихся к порядку его применения», то необходимо заметить, что Суд ЕC в своих решениях подразумевает под этим «нормы международного права и общие принципы права». Подобный вывод содержался в ряде решений: Fédération Charbonnière de Belgique v. High Authority ${ }^{39}$, International Fruit Company v. Produktschap voor Groenten en Fruit ${ }^{40}$, Van Duyn v. Home Office ${ }^{41}$, Roche $^{42}$ и т.д.

4. Злоупотребление властью. Суд ЕС довольно редко использовал данное основание для аннулирования акта института Сообщества. Одним из немногих примеров является дело Simmenthal ${ }^{43}$.

\footnotetext{
${ }^{36}$ Дело C-303/90, France v. Commission, [1991] ECR I-5340.

${ }^{37}$ Дело C-366/88, France v. Commission, [1990] ECR I-3595.

${ }^{38}$ См. Дело С-6 \& 11/69, Commission v. France, [1969] ECR 523 (11-13).

${ }^{39}$ Дело 8/55, Fédération Charbonière de Belgique v. High Authority, [1954-[956] ECR 245 (299).

${ }^{40}$ Дело 21 \& 24/72, International Fruit Company v. Produktschap voor Groenten en Fruit, [1972] ECR 1219 (1226(6)).

4 Дело 41/74, Van Duyn v. Home Office, [1974] ECR 1337 (1351 (22)).

42 Дело C-162/96, Racke, [1998] ECR I-1606 (25-27).

${ }^{43}$ Дело 92/78 Simmenthal v. Commission, [1979] ECR 777 (811 (106)).
} 
В результате аннулирования акта института Сообщества Суд ЕС объявляет данный акт недействительным, а Институт, выпустивший акт, признанный недействительным, обязан в соответствии со ст. 233 Договора об учреждении Европейского Сообщества принять все меры для выполнения решения Суда. Как указано в деле Antillian Rice Mills ${ }^{44}$, это подразумевает «устранение последствий принятия и вступления В силу аннулированного акта», а также «восстановление положения status quo» и «воздержание от аналогичных мер» ${ }^{45}$.

Не менее важным является также иск о бездействии в рамках полномочий Суда, предусмотренных в ст. 232 Договора о ЕС. Так же как и в случае с жалобами на нарушение права Сообщества, в данном случае Суд имеет полномочия рассматривать вопрос о нарушении Договора в случае, если институты (включая ЕЦБ) не предприняли необходимых мер.

Третья, и последняя, группа исков связана с возмещением вреда из неисполнения договорных обязательств, а также с внедоговорной ответственностью Сообшества. Как уже указывалось выше, в практике Суда сформировался особый подход к задачам данной группы исков: Суд склонен унифицировать ответственность государств-членов и Сообщества из нарушения права Сообществ (сюда включаются и договорные обязательства). В Учредительном договоре внедоговорная ответственность, однако, рассматривается отдельно в ст. 235. Впрочем, и в судебной практике иски из внедоговорной ответственности стоят несколько особняком. Так, например, для вчинения иска не требуется признания конкретного акта Сообщества, в результате применения которого и возник ущерб ${ }^{46}$, недействительным. Подобная позиция Суда ЕС представляет собой средство совершенствования эффективности зашиты интересов истцов в связи с тем, что для предварительного признания акта недействительным требуется подавать отдельный иск, в то время как, например, в рамках процедуры косвенного обжалования можно обратиться и с вопросом о признании конкретного акта Сообществ недействительным.

\footnotetext{
44 Дело Т-480 \& 483/93, Antillian Rice Mills, [1991] ECR I-2310.

is Ibidem, ECR I-2310 (60).

46Европейское право / Под ред. Л.М. Энтина. - М., 2000. С. 193.
} 


\section{Юрисдикция Суда ЕС в сфере прав человека}

и основных свобод.

Отдельный проблемный вопрос - это применение Европейской конвенции по защите прав человека и основных свобод. Как известно, в 1994 году по запросу Комиссии о возможности присоединения ЕС к Конвенции Суд ЕС ответил, что ЕС не обладает достаточными полномочиями для этого. Тем не менее, Суд ЕС применяет данную конвенцию, как часть «общих для государств-членов принципов права» ${ }^{4}$. Таким образом, нельзя говорить, что Римская конвенция 1950 года является источником права ЕС в строгом смысле этого слова.

Однако на определенном этапе развития права ЕС стало совершенно ясно, что заставить национальные суды применять принципы верховенства и прямого действия будет чрезвычайно сложно до тех пор, пока институты Сообщества не будут обязаны соблюдать основные права и свободы ${ }^{48}$. Эта проблема представлялась настолько серьезной в государствах-членах, что спровоцировала появление решений Конституционного Суда ФРГ и Италии относительно вопроса соблюдения прав человека ${ }^{49}$. В результате конфликта юрисдикций, в ходе которого Суд ЕС взял на себя исключительную компетенцию гарантировать соблюдение прав человека в Европейском Сообществе ${ }^{50}$, появились решения конституционных судов ФРГ и Италии, в которых они признавали доктрину верховенства права ЕС и прямого действия, хотя и сохранили за собой право обрашаться к вопросу соблюдения прав человека в случае, если Суд ЕС, по их мнению, будет в недостаточной степени защищать и гарантировать права человека ${ }^{51}$. В данном случае Суд ЕС действовал, фактически выйдя за рамки, предусмотренные

${ }^{47} \mathrm{C}$. F Маастрихтского доповора / Договор о Европейском Союзе / Под ред. Ю.А. Борко, М.В. Каргалова, Ю.М. Юмашева - М., 1994. С. 51.

${ }^{48}$ Russel M. Dallen. An Overview of European Community Protection of Human Rights // CMLR - 1990. № 27. P. 761, 766.

${ }^{49}$ Дело Internationale Handelsgeselischaft $\mathrm{mbH}$ v. Einfür- und Vorratstelle Für Getreide und Futtermittel, 2BvL 52/71, 37 BverfGE 271 (Solange I).

${ }^{50}$ Дело 44/79, Liselotte Hauer v. Land Rheinland Pfalz, [1979] ECR 3727.

"Joseph H.H.Weiler. Eurocracy and Distrust: Some Questions Concernity the Role of the European Court of Justice in the Protection of Fundamental Rights / Washington Law Review. - 1986 - № 61 - С. 1103, 1118-19 касательно дела Wunsche Handelsgesellschaft (Solange II), Case 2 BvR 197/83, 73 B Verf. GE 339; S.p.a. Granital v. Amministrazione delle Finanze dello Stato // Common Market Law Review. - 1984. № 21. P. 756. 
Учредительными актами. Суд $\mathrm{EC}$, обратившись к защите прав человека, конечно, действовал в рамках ст. 220 Договора о $\mathrm{EC}$, но в результате появилось новое юрисдикционное поле. В связи с этим, как представляется, необходимо обратиться к тем решениям, которые были приняты в этой области Судом ЕС.

Основными судебными решениями, на которые автор хотел бы обратить внимание, можно назвать решения ERT и Konstantinidis ${ }^{32}$.

В отличие от нарушений основных прав человека актами Сообщества, довольно долго существовала концепция, согласно которой Суд $\mathrm{EC}$ не обладал достаточной компетенцией для надзора за государствами-членами в вопросе соблюдения прав человека. Центральным судебным решением в этой области можно назвать Gabrielle Defrenne v. Sociète Anonyme Belge de Navigation Aerienne Sabena ${ }^{53}$. B заключении по этому делу генеральный адвокат Капоторти указал: «Правоотношения, регулирование которых находится в компетенции национальных законодательных органов, должны рассматриваться в рамках конституционного принципа соблюдения прав человека отдельного государства-члена до тех пор, пока подобные правоотношения не станут предметом регулирования актов Сообщества» ${ }^{54}$.

Иную позицию занял Суд ЕС в день Rutili v. Minister for the Interiorss. Рутили, итальянский гражданин, домицилированный во Франции, получил разрешение на постоянное проживание от французского Министерства внутренних дел с оговоркой о том, что ему не будет позволено проживать в определенных регионах страны. Французское правительство, выступая в роли ответчика, ссылалось на оговорку об «общественном порядке» ст. 48 (3) ${ }^{56}$. Таким образом, основным вопросом в ходе служебных слушаний стала точная интерпретация формулировки статьи: «ограниченное соображениями общественного порядка, общественной безопасности» ${ }^{57}$. Суд в решении по данному делу,

\footnotetext{
52Дело 260/89, Elliniki Radiofonia Teleorasi - Anonimi Etairia [ERT-AE] v. Dimotiki EP, [1991-6] ECR I-2925; Case 168/91, Christos Konstantinidis v. Stadt Altensteig, Standesamt, Landratsamt Calw und Ordnungsamt, [1993] ECR I-1191.

${ }^{53}$ Дело 43/75, Gabrielle Defrenne v. Sociète Anonyme Belge de Navigation Aerienne Sabena, [1978], ECR 1365.

${ }^{54}$ Ibidem, 1384

\$Дело 36/75, Rutili v. Minister for the Interior, [1975], ECR 1231.

${ }^{56} \mathrm{CM}$. Договоры, учреждающие ЕС/ Под ред. Ю.А. Борко, М.В. Каргаловой, Ю.М. Юмашева. - М., 1994. С. 132.

${ }^{57}$ Ibidem.
} 
тем не менее, вынес решение о том, что содержание данной оговорки подлежит контролю институтами Сообшества. Затем Суд подверг пересмотру некоторые положения вторичного права Сообщества, имевшие отношение к отределению содержания указанной оговорки ${ }^{58}$.

Что же касается нарушений прав Рутили во Франции, Суд указал, что «подобные ограничения, возложенные на государства-члены, в отношении контроля над перемещениями иностранцев представляют собой более конкретное отражение применения принципа, изложенного в статьях $8,9,10,11$ Конвенции о защите прав человека и основных свобод, а также в ст. 2 Протокола № 4 к Конвенции, которая предусматривает, что никакие ограничения в интересах национальной безопасности или общественного порядка не могут быть препятствием для осуществления прав, перечисленных в вышеуказанных статьях, за исключением тех случаев, которые допустимы для защиты данных интересов в демократическом обществе ${ }^{59}$. Таким образом, Суд счел возможным отменить решение национальных властей на том основании, что оно нарушает положения Римской конвенции 1950 года. Это решение подтолкнуло появление ряда не менее важных решений, в которых Суд ЕС существенно пересматривал свою позицию в сторону расширения своих полномочий. Одним из ключевых решений можно назвать решение по делу Lynne Watson \& Alessandro Belmann ${ }^{60}$. В ходе судебных слушаний был поднят вопрос о законности положений итальянского законодательства, согласно которому гражданин иного государства-члена, а также любое лицо, которое принимало данного гражданина на работу, обязательно уведомить национальные власти в течение определенного срока о въезде данного гражданина в Италию. В случае нарушения данного положения на гражданина Италии накладывалась санкция в виде штрафа или тюремного заключения, а иностранца - высылали из страны. Госпожа Ватсон, гражданка Великобритании, и господин Белманн, итальянский гражданин, отправивший ей приглашение, были привлечены к ответственности за нарушение указанньх требований. Генеральный адвокат Трабукки, подготовивший доклад Суду ЕС, после того как итальянский суд направил запрос, указал, что данное требование нарушает положение статей 8 и 14 Римской конвенции 1950 года ${ }^{61}$. Генеральный адвокат в сво-

${ }^{58}$ Council Directive 64/221, 1964 OJ (L563) 850; Council Regulation 1512/68, 1986 OJ (L257) 2.

${ }^{59}$ Дело 36/75, Roland Rutili v. Minister for the Interior, [1975] ECR 1231.

${ }^{\circ}$ Дело 118/75, Lynne Watson \& Alessandro Belmann, [1976] ECR 1185. 
ем заключении также указал, что «при решении вопроса о законности действий и решений государств-членов критерий соблюдения прав человека может сыграть огромную роль в сфере применения права Сообщества... Суд ЕС имеет полномочие рассматривать вопрос о нарушении прав человека и основных свобод государством-членом в той же степени, в какой он имеет право рассматривать вопрос о действительности актов Сообщества, в той степени, в какой нарушенные права человека связаны с защитой экономических прав, являющихся объектом защиты Договоров ${ }^{62}$.

Суд, принимая решение по делу, согласился с доводами генерального адвоката, хотя и сформулировал свой вывод в несколько ином ключе. Суд подчеркнул, что национальные требования подобного характера могут иметь место при условии соблюдения принципа «разумности» в отношении сроков извещения либо санкций в случае нарушений. Именно соблюдение общих принципов права подразумевает гарантии соблюдения прав человека и основных свобод ${ }^{63}$. В последующих решениях Суда по делам: Cinetheque S.A. v. Fédération Nationale des Cinémas Francais ${ }^{64}$, Johnston v. Chief Constable of the Royal Ulster Constabulary $(« \mathrm{RVC} »)^{65}$, Marthe Klensch v. Secrétaire d'Etat à L'àgriculture et à la viticulture ${ }^{66}$ Суд окончательно сформулировал свой подход к проблеме соблюдения прав человека и основных свобод в действиях и решениях государств-членов. Суть его заключается в том, что соблюдение основных прав и свобод, перечисленных в Европейской конвенции 1950 года, представляет собой выражение «конституционного принципа, общего для государств-членов..., который подлежит соблюдению и в праве Сообществ» ${ }^{67}$.

\footnotetext{
${ }^{61} \mathrm{Cr} .8$ Конвенции говорит о праве человека «на уважение его частной и семейной жизни, его жилища и корреспонденции»; ст. 14 запрещает все формы дискриминации человека по каким бы то ни было признакам. См. Конвенцию о защите прав человека и основных свобод, М., 1996, С. 9, 11.

${ }^{62}$ Дело 118/75, Lynne Watson \& A.Bellmann, [1976] ECR 1206-07.

${ }^{63} \mathrm{Joseph}$ H.H.Weiler. Methods of Protection: Towards a Second and Third Generation of Protection, European Union / The Human Rights Challenge. Casses et al. Eds. - London, 1991. P. 555, 572.

${ }^{64}$ Дело 60, 61/84, Cinetheque S.A. v. Fédération Nationale des Cinémas Francais, [1985] ECR 2605.

${ }^{65}$ Дело 222/84, Johnston v. Chief Constable of the Royal Ulster Constabulary, [1986] ECR 1651. ${ }^{66}$ Дело 201, 202/85, Marthe Klensch v. Secrétaire d'Etat à L'agriculture et à la viticulture, [1986] ECR 3477.

${ }^{67}$ Дело Johnston, [1986] ECR 1682.
} 
Таюже необходимо обратиться к рассмотрению дела ERT, или Elliniki Radiofonia Tileorasi-Anonimi Etairia v. Dimotiki ${ }^{68}$, в котором Суд впервые поднял вопрос о своей компетенции рассматривать споры о законностн актов и действий государств-членов на основе Учредительных договоров. Суть дела заключается в том, что ERT, радио- и телевешательная компания в Греции, получила исключительные права на передачу и ретрансляцию теле- и радиосигнала на территории Греции. Законодательство требовало получения разрешения ERT для осуществления аналогичной деятельности иными лицами. В нарушение этого закона мэр г. Фессалоники и компания "Dimotiki Etairia Pliroforissis» открыли телевизионный канал в 1988 году.

ERT обратилась в Суд в Фессалониках. «DEP» в отзыве на иск указала, что существование подобной монополии нарушает положения Учредительного договора о свободном движении товаров и услуг, нормы права конкуренции, а также ст. 10 (1) Европейской конвенции о запите прав человека и основных свобод ${ }^{69}$. Суд в Фессалониках занял позицию, изложенную Судом ЕС в деле «Cinetheque»: Суд ЕС не имеет полномочий рассматривать вопрос о соблюдении прав человека и основных свобод индивида государством-членом, если данный вопрос не связан с вопросом соблюдения обязательств государствачлена, принятых согласно Учредительному договору ${ }^{70}$.

Суд ЕС, рассматривая впоследствии данное дело, вопреки позиции Генерального адвоката Ленца ${ }^{71}$, указал, что Суд ЕС тем не менсе имеет право рассматривать вопрос о соблюдении прав человека, поскольку они являются неотьемлемой частью общих принципов права Сообщества, а значнт, имеют прямую связь с обязательствами государств-членов согласно Учредительному договору ${ }^{72}$. Таким образом, Суд ЕС существенным образом расширил свою юрисдикцию, включив в свою компетенцию право рассматривать дела, связанные с соблюдением государствами-членами прав и свобод граждан, которые гарантируются Европейской конвенцией о защите прав человека и основных свобод и которые имеют тесную связь с правами экономического характе-

Дело 260/89, Elliniki Radiofonia Tileorasi-Anonimi Etairia v. Dimotiki v. Dimotiki Etairia Pliroforissis, [1991-6] ECR 1-2925.

6В стапь 10 (1) говориться о защите права на свободу выражения своего мнения. См. Конвенџню о защите прав человека и основных свобод. М., 1996 С. 9.

"Лело ERT, [1991-6] ECR I-2931.

"Ibidem, I-2948.

'Tbidem, 1-2964. 
ра, гарантированными Учредительным договором. Впоследствии данный подход получил свое закрепление в деле «Society for the Protection of Unborn Children Ireland Ltd. (SPVC) v. Grogan $\rangle^{73}$.

Однако данный подход к правам человека, как отмечают некоторые специалисты $^{74}$, будет в дальнейшем расширяться в сторону поддержки всеобъемлющей защиты прав человека Судом ЕС. Так, в уже упоминавшемся деле Christos Konstantinidis, генеральный адвокат Якобс, отмечая общую тенденцию в доктрине права ЕС, приходит к выводу о необходимости именно полномасштабной защиты прав человека в Суде $\mathrm{EC}^{75}$. Суд, рассматривая вопрос о природе Сообщества, показал, как представляется автору, свою готовность в будущем поддержать позицию генерального адвоката ${ }^{76}$.

Это нашло свое отражение и в судебном решении по данному делу. Суд не подтвердил свою позицию в отношении вопроса об основных правах и свободах, но и не опроверг ее. Однако, тем не менее, дело Konstantinidis представляет собой очень важный шаг в вопросе пересмотра границ полномочий Суда ЕС. Для обоснования своей позиции генеральный адвокат использовал доктрину «подразумеваемой юрисдикциин Суда, которая позволит более эффективно выполнять задачи, возложенные Учредительным договором на Суд $\mathrm{EC}$, однако не предусмотренные договорами в прямой форме. Суд вплотную подошел к пересмотру целей Сообщества от «стремления укрепить единство экономики своих стран» ${ }^{77}$ к стремлению «заложить основы для все более тесного союза европейских народов» ${ }^{78}$, что позволит существенным образом пересмотреть объем полномочий Суда ЕС в институциональной структуре ЕC.

Пересмотр позиции Суда ЕС в отношении установления единых стандартов защиты прав человека, превышающих стандарты государств-членов, возможно, наиболее эффективно способствовал бы ста-

\footnotetext{
${ }^{73}$ Дело C-159/90, SPVC v. Groigan, [1991], ECR I-4685.

${ }^{74}$ Darcy S.Binder. The European Court of Justice and the Protection of Fundamental Rights in the European Community/1995, EUI Working Paper P. 27-28; cM. rakoke Louis Charlentier. The European Court of Justice and the rhetoric of affirmative action. European University Institute, Working Paper RSC No 98/30. P. 23, 24.

${ }^{73}$ Case C-168/91, Christos Konstantinidis.

${ }^{76}$ Darcy S. Binder. Op. cit. P. 31.

${ }^{77}$ Договоры, учреждающие Европейские Сообщества / Под ред. Ю.А. Борко, М.В. Каргаловой, Ю.М. Юмашева - М., 1994. С. 97.

${ }^{78}$ Ibidem.
} 
новлению «тесного союза европейских народов», поскольку позволило бы Суду ЕС пересматривать решения и действия национальных органов власти в отношении как иностранцев, так и собственных граждан $^{79}$. Положения договора, учреждающего Европейский Союз, о котором автор уже упоминал ${ }^{80}$, не содержат нового импульса к пересмотру объема компетенции ЕС, и Суда ЕС в частности. В данном случае Маастрихтский договор лишь зафиксировал норму, уже сформулированную Судом ЕС.

\section{Проблема ГАТТ-ВТО. Конституционная роль Суда ЕС}

В данном параграфе автор рассмотрит важнейшие вопросы, связанные с компетенцией Суда ЕС в рамках функциональной структуры ЕС.

Во-первых, необходимо рассмотреть один из сложнейших вопросов, связанных с юрисдикцией Суда ЕС, а именно вопрос о месте в acquis communautaire положений Договора ГАТТ (Генерального Сoглашения о тарифах и торговле). Как известно, государства - члены ЕС самостоятельно подписывали соглашения в рамках ГАТТ-ВТО. Рассмотрев пример с Соглашением о тарифах и торговле, а также с соглашениями 1994 года (иначе известны как соглашения Уругвайского раунда), автор считает необходимым проанализировать весьма актуальный вопрос о компетенции Сообщества и его институтов являться субъектами подобных соглашений, а также полномочия Суда, связанные с использованием подобных соглашений в качестве источника права EC.

Впервые Суд ЕС обратился к проблеме соглашений в рамках ГАТТВТО в 1972 году в деле International Fruit Company v. Produktschap voor Groenten en Fruit" ${ }^{81}$ В решении по данному делу Суд, ссылаясь на «характер и цели соглашения ${ }^{82}$, установил, что положения ГАТТ не явля-

${ }^{79}$ О6 этом, в частности, пишет Дарси С. Биндер, op. cit. cтр. 46, a также Manfred A.Dauses. The Protection of Fundamental Rights in the Community Legal Order // European Law Review. 1985. № 10. P. 398-399, 419; J.Frowein. Fundamental Human Rights as a Vehicle of Legal Integration / Integration Through Law: Europe and the American Federal Experience. M.Cappelletti et al. Eds - New York, 1986. P. 300, 302.

${ }^{80} \mathrm{C}$. 6 (1) и (2) Маастрихтского договора.

${ }^{2 \prime}$ Дело 21-24/72, International Fruit Company v. Produktschap voor Groenten en Fruit, [1972] ECR 1219.

82Tbidem, ECR 1227 (18). 
ются источником права ЕС и не обладают прямым действием в ЕС. Однако постепенно Суд подошел к пересмотру роли подобных Соглашений, что в первую очередь связано с пересмотром объема компетенций Сообщества и развитием принципа субсидиарности. Суд в решениях по многим делам, например, Commission v. Council ${ }^{83}$, Cornelis Kramer and Others ${ }^{84}$ и т.д., пришел к следующему определению полномочий Сообщества: «Если право Сообществ предоставляет Институтам Сообщества полномочия ... для достижения определенной цели, Сообщество обладает полномочием заключать международные соглашения ... для достижения поставленной цели» ${ }^{85}$. Однако путь Суда ЕС по признанию прямого действия ГАТТ в ЕС был долгим. Сначала было лишь признание обязательной силы для ЕС положений ГАТТ ${ }^{86}$. Это признание нашло свое отражение в решении по делу Nederlandse Spoorwegen v. Inspecteur der Invoerrechten en Accijnzen ${ }^{87}$. Лишь впоследствии в решениях по делу Amministrazione delle Finanze dello Stato v. SPI and SAMI ${ }^{88}$, a также Singer and Geigy v. Amministrazione delle Finanze dello Stato ${ }^{89}$ Суд вплотную подошел к признанию прямого действия Соглашения в ЕС. Данный случай представляет собой идеальный пример вытеснения государств-членов из сферы их традиционной юрисдикции. Особенностью соглашений в рамках ГАТТ-ВТО заключается в том, что в основном их предмет касается отношений между государствами-членами в сфере свободной торговли и урегулирования споров в сфере тарифов и торговли. При этом оно обладает прямым действием в ЕС, которое в рамках структуры ВТО является единым участником вместо стран-членов.

Любопытно, что Суд, решая дилемму о прямом действии ГАТТ в ЕС, пришел к несколько неожиданной формуле обоснования прямого действия подобных международных соглашений: в делах Kupferberg $^{90}$, Bresciani v. Amministrazione Italiana delle Finanze ${ }^{91}$ и д.p. ${ }^{83}$ Дело 22/70, Commission v. Council (AETR), [1971] ECR 263.

84 Дело 3, 4, 6/76, Cornelis Kramer \& Others, [1976] ECR 1279.

${ }^{83}$ Opinion of the Court 2/91, ECR 1308 (17-18).

${ }^{86}$ P.S.R.F. Mathijsen. Op. cit. P. 462.

${ }^{87}$ Дело 38/75, Nederlandse Spoorwegen v. Inspecteur der Invoerrechten en Accijnzen, [1975] ECR 1439.

${ }^{88}$ Дело 267-269/81, Amministrazione dello Finanze dello Stato v. SPI and SAMI, [1983] ECR 801.

${ }^{89}$ Дeл1 290-291/81, Singer and Geigy v. Amministrazione delle Finanze dello Stato, [1983] ECR 847.

${ }^{90}$ Дело 104/81, Kupferberg, [1982] ECR 3641.

${ }^{9}$ 'Дело 87/75, Bresciani v. Amministrazione Italiana delle Finanze, [1076] ECR 129. 
Суд установил, что подобные международные соглашения, в которых ЕС является стороной, будут иметь прямое действие в случае, если, принимая в расчет цели и характер соглашения, оно будет содержать «ясное и точное обязательство», обязательность которого не должна зависеть от последующих соглашений ${ }^{92}$.

Таким образом, можно увидеть, что Суд ЕС в значительной степени дополнил определенные пробелы в компетенции Сообщества в отношении международных соглашений подобного характера. Прежде всего следует отметить тот факт, что Суд ЕС, принимая решение по вопросу о прямом действии соглашений в рамках ГАТТ-ВТО, закрепил свои полномочия толковать не только положения права Сообщества, но и цели создания Сообщества, что представляет собой новый подход Суда к объему своих полномочий.

Здесь возникает вопрос, который в зарубежной литературе получил следуюшую формулировку. Является ли Суд ЕС конституционным Судом? Именно этот вопрос хотелось бы рассмотреть следующим. Известно, что не во всех странах - членах ЕС известен подобный институт конституционного контроля. Иначе говоря, можно ли рассматривать Суд ЕС как орган, имеющий исключительную компетенцию рассматривать споры, касаюшиеся основ Собшества, а также осуществлять контроль за нормативно-правовой деятельностью в Сообществе посредством активного нормотворчества (включая внесение поправок и вынесение решений, противоречаших положениям Договоров).

Если обратиться к деятельности самого Суда, то можно обнаружить, что сам Суд давно уже последовательно отстаивает свое особенное положение в институциональной системе. Так, например, в Заключении Суда $1 / 91^{93}$, а также в ряде дел ${ }^{94}$ Суд активно защищает свое неограниченное право толкования. Об этом говорится и в трудах многочисленных признанных специалистов по праву ЕС. Так, например, Хоув $^{95}$, Арнулл ${ }^{96}$, Куртин $^{97}$, считают активную нормотворческую пози-

${ }^{92}$ Ibidem, ECR 141 (23).

${ }^{93}$ [1991] ECR 6079.

${ }^{94}$ Дело 294/83, Parti Ecologiste «Les Verts» v. European Parliament, [1986], ECR 1339.

${ }^{95}$ G.Howe. Euro-justice: Yes or No? // European Law Review. - 1966. \#21. P. 187, 191.

${ }^{\circ}$ A.Amull. The European Court and Judicial Objectivity // Law Quarterly Review. - 1996. № 112. P. 95; см. также работу Mattias Kamm. Who is the Final Arbiter of Constitutionality in Europe? Harvard Law School, Jean Monnet Chair Working Papers, 1998. P. 38.

${ }^{97}$ Constitutional Adjudication in EC and National Law. ed. D.Curtin and D.O'Keefe. Butterworths, 1992. P. 25, 32. 
цию Суда $\mathrm{EC}$ неотъемлемой частью нормального функционирования и развития Сообщества. Суд ЕС уже открыто заявлял о своем праве руководствоваться политическими мотивами в принятии решений по конкретным вопросам, несмотря даже на тот факт, что они [решения] могут зачастую расходиться и с полномочиями Суда ЕС, предусмотренными в Учредительном договоре, и даже, как может показаться, с положениями самого Договора. Наиболее ярким примером подобной «конституционной» активности Суда ЕС можно назвать судебное дело Parti Ecologiste «Les Verts» v. European Parliament ${ }^{98}$. Суд EC, который давно заявил о своих «федералистских» симпатиях в политике, часто максимально широко интерпретирует положения Договоров, противоречащих, по его мнению, главной цели Сообщества: «тесного Союза европейских народов) ${ }^{99}$. Суд вопреки действию ст. 173 (сейчас ст. 230) решил, что акты Парламента подлежат контролю за законностью со стороны Суда ЕС. Дело в том, что в 1986 году, когда было вынесено решение по делу, Суд ЕС не обладал подобными полномочиями, т.к. Парламент не принимал актов, которые затрагивали бы интересы третьих лиц (за некоторыми исключениями). Таким же образом поступал Суд и в делах «Chernobyl» ${ }^{100}$ и «SPI» ${ }^{101}$. Bce вышеприведенные судебные дела служат прекрасной иллюстрацией того, как Суд изменяет право, вместо того чтобы толковать его Можно привести еще несколько весьма характерных примеров (e.g. Defrenne) ${ }^{102}$.

Что касается доктрины, то некоторые известные ученые склонны оценивать подобную практику Суда ЕС как положительный опыт, поскольку он позволяет в наилучшей степени следить за соблюдением верховенства права $\mathrm{EC}^{103}$. Как представляется, политическая активность Суда - это utilitas dubius, поскольку таким образом можно легко обесценить все достижения интеграции, среди которьх право Сообществ - самое главное.

Данная проблема является одной из самых важных, поскольку самым серьезным образом меняет подход к компетенции Суда ЕС, что и является целью рассмотрения настоящей статьи. Подводя итоги вы-

\footnotetext{
${ }^{98}$ Дело 294/83, Parti Ecologiste «Les Verts» v. European Parliament, [1988] ECR 1339. ${ }^{99}$ Преамбула Договора, учреждающего Европейское Сообщество / Договоры, учреждаюшие ЕС/ Под ред. Ю.А. Борко, В.М. Каргаловой, Ю.М Юмашева. М., 1994. С. 99. ${ }^{100}$ Дело С-70/88, European Parliament v. Council, [1990] ECR 1-2041.

${ }^{10}$ Объединенное дело 267-9/81 [1983] ECR 810.

${ }^{102}$ Дело 43/75, Defrenne v. Sabena, [1976] ECR 455.

${ }^{103}$ Хартли. Основы права ЕС. М.,1998. С. 94.
} 
шесказанному, необходимо заметить, что Суд ЕС, действуя на основе Учредительного договора и руководствуясь в не меньшей степени своими представлениями о собственной роли и компетенции в ЕС, которые находят свое выражение в многочисленных судебных решениях, выполняет чрезвычайно важную функцию: активно участвует в формировании и внесении изменений в правовую систему Сообщества. Как уже отмечалось в предыдуших параграфах, Суд посредством толкования положений договоров, восполняет пробелы в своей компетенции и решает важнейшие вопросы, связанные с источниками права Сообщества, как, например, основные права и свободы человека, международные договоры и т.П. На основе рассмотренных выше судебных дел можно прийти к выводу, что Суд ЕС, во многом благодаря своей активной позиции в области расширения своей юрисдикции, смог разрешить некоторые из тех многочисленных проблем, которые возникали с момента создания сообществ. Как уже подчеркивал автор, Суд $\mathrm{EC}$, пытаясь более эффективно вмешиваться в ход интеграции и претендуя на роль ее движущей силы, склонен руководствоваться своими политическими пристрастиями, нежели нормами права.

Каков же главный вывод, который можно сделать на основании всего вышесказанного в настоящей статье?

Отвечая на вопрос о роли Суда $\mathrm{EC}$, его функциях и полномочиях в институциональной структуре Союза, необходимо сказать, что Суд ЕС претендует на роль значительно большую, нежели может показаться из анализа статей Учредительного договора. Функции и полномочия Суда ЕС, безусловно, основываются на положениях договора о ЕС. Однако, как уже было отмечено, Суд ЕС, во-первых, детально проработал в своих судебных решениях вопросы, связанные с источниками права ЕC, включив туда права человека, а также международные соглашения, цель которых совпадает с целями Сообщества; во-вторьх, наладил четкий механизм судебных гарантий соблюдения права Сообществ посредством исков, перечисленных в Учредительном договоре; в-третьих, расширительно толкует объем своих полномочий, что позволяет ему решать задачи, связанные с судебными гарантиями и поиском наиболее эффективных средств обеспечения соблюдения права ЕС. Поскольку решения Суда часто опережают готовность государств-членов принять подобные решения и признать компетенцию Суда (в т.ч. и в сфере прав человека, как это происходило в Италии и ФРГ), это порождает массу проблем. Одной из основных проблем 
в этой связи остается вопрос о «конституционной» роли Суда в ЕС. Может ли Суд ЕС в условиях развивающейся правовой системы Европейского Союза, самостоятельно формулируя объем собственной компетенции, претендовать на роль «конституционного» суда, решения которого могут основываться на политических мотивах, на представлениях о том, «соmme il faudrait», а не на правовых предписаниях.

Необходимо добавить, что модель функционирования Суда EC, основанная на правовых нормах о его компетенции, рассмотренных нами в настоящей статье, показала, что способна работать без сбоев лишь при условии соблюдения принципов, изложенных в учредительных договорах. Именно в этом заключается ключ к эффективности деятельности Сообщества, его правовой системы. 